\title{
DIALEKTIKA RELASIONAL ORANG TUA DAN ANAK DALAM PROSES BELAJAR DI ERA COVID-I 9
}

\author{
Adi Putra Parlindungan Lubis
}

Universitas Paramadina

\begin{abstract}
The transmission of Covid-19 in Indonesia has made the government stipulate that all activities must be carried out from home, including studying. During learning from home the children are accompanied by their parents. The togetherness of parents and children while learning from home makes their relationship even closer. Apart from that, there are things that are contradictory in their relationship. Their disagreement with something when studying creates dialectics. By using qualitative methods and a phenomenological approach, the purpose of this study is to analyze the relational dialectic that occurs between parents and children from families in Kampung Tengah Kramat Jati Jakarta Timur during the learning process in the Covid-19 era. The theory used in this research is relational dialectic and family relationship theory. The informants are mothers who have school-age children at primary school level 2-3 who are busy taking care of the house while accompanying their children to study. The results of the study are dialectics due to the inequality of mothers and children in responsibilities, expectations and perceptions. The reality of their relationship is in the form of contradictions because mothers tend to be emotional, and children are disorderly and tend to be spoiled.
\end{abstract}

\author{
Keywords \\ Learning from Home, Relational \\ Dialectics, Relationship, Covid-19
}

Correspondence Contact

adi.lubis@students.paramadina.ac.id

\section{PENDAHULUAN}

Belajar dari rumah merupakan proses yang baru. Dimulai sejak 2 Maret 2020 pada saat Covid19 masuk ke Indonesia dan menjangkit sejumlah orang (bebas.kompas.id, 2020) membuat pemerintah Republik Indonesia menetapkan langkah cepat agar semua aktivitas di luar rumah segera dialihkan ke rumah termasuk kegiatan belajar (nasional.kompas.com, 2020). Imbauan pemerintah pusat tersebut kemudian diperkuat dengan kebijakan Pembatasan Sosial Berskala Besar (PSBB) yang dibuat oleh pemerintah daerah termasuk DKI Jakarta. PSBB ini menjadi dasar agar orang-orang bisa membatasi diri dengan tidak lagi melakukan kontak fisik dengan leluasa, berkumpul tanpa menjaga jarak, atau sengaja mendatangani kerumunan. Hal-hal tersebut merupakan kemungkinan yang bisa terjadi pada anak-anak pada saat mereka berada di sekolah.

PSBB di DKI Jakarta dimulai pada 10 April 2020 dan telah dievaluasi serta diperpanjang menyesuaikan dengan keadaan darurat peningkatan kasus positif Covid-19 (cnnindonesia.com, 2020). Melalui Peraturan Gubernur DKI Jakarta, PSBB pada sektor pendidikan juga diatur. Selain itu, Kementerian Pendidikan dan Kebudayaan Republik Indonesia pun turut memperjelas aturan PSBB ini. Melalui Surat Edaran Nomor 15 Tahun 2020, proses belajar dari rumah diatur dengan tetap mengutamakan pemenuhan kebutuhan anak-anak sekolah serta melindungi mereka dari dampak buruk penularan Covid-19 (kemdikbud.go.id, 2020). 
Meski sudah ada pedoman terkait pelaksanaan kegiatan belajar dari rumah tersebut, namun karena ini adalah proses yang baru, maka dari itu tidak mudah untuk diadaptasi dengan cepat. Sejumlah hal yang perlu disiapkan dengan baik antara lain media yang memadai, guru-guru yang cepat tanggap dengan kondisi belajar jarak jauh, orang tua yang siap sedia mendampingi anak-anaknya, dan kesiapan anak-anak itu sendiri untuk menerima pembelajaran dari jarak yang jauh.

Mengalihkan kegiatan belajar dari sekolah ke rumah adalah upaya untuk mengatasi masalah penularan Covid-19 pada lingkup anak-anak sekolah. Namun pengalihan ini nyatanya menimbulkan masalah-masalah baru (edukasi.kompas.com, 2020). Misalnya masalah terkait pemahaman anak-anak sekolah terhadap materi yang disampaikan oleh para gurunya. Semula mereka mudah memahami materi pembelajaran karena disampaikan dalam jarak yang dekat dan mereka dapat berinteraksi dengan para gurunya tanpa sekat. Sedangkan proses belajar dari rumah pada era Covid-19 yang menggunakan media daring membuat mereka rentan menghadapi sejumlah hambatan seperti jaringan internet yang tidak stabil, gawai yang digunakan tidak memadai, atau penjelasan materi yang tidak komprehensif dari para guru sehingga sulit dipahami oleh anak-anak sekolah.

Pada saat anak-anak sekolah mengalami kendala dalam proses belajarnya di rumah, maka orang tua adalah pihak pertama yang mereka temui. Terkhusus untuk masalah pemahaman materi pembelajaran, pada akhirnya orang tua pun dituntut untuk memiliki pemahaman yang cukup atas materi tersebut serta pemahaman terkait cara mendidik anak dengan baik sehingga pembelajaran di rumah berlangsung dengan baik (Trisnawati \& Sugito, 2021: 824). Tidak hanya itu, ada beberapa hal yang dapat memengaruhi cara orang tua dalam mendidik anaknya yaitu karakter orang tua itu sendiri, dan kepribadian mereka yang bersemangat, sabar, dan mau belajar agar mereka turut memahami materi-materi pembelajaran anak sekolah (Hurlock dalam Cahyati \& Kusumah, 2020: 154).

Penelitian sebelumnya oleh Harmaini (2013: 92) yang dilakukan pada keluarga dengan anak yang bersekolah pada Sekolah Dasar menyimpulkan bahwa orang tua yang bekerja tidak memiliki cukup waktu untuk menemani anak mereka dalam kegiatan belajar sehingga mereka cenderung vakum pada saat sang anak menemukan kendala dalam pelajaran sekolahnya. Pada era Covid-19 keadaan tersebut berubah. Orang tua harus duduk bersama anak-anaknya selama proses belajar. Dalam kondisi ini tercipta pengalaman baru di mana mereka bisa saling berdiskusi terkait pelajaran sekolah, bertukar pendapat, atau mencurahkan perasaannya di tengah situasi pandemi yang membosankan karena semua orang harus berada di rumah. Namun pengalaman ini tentu tidak senantiasa berjalan dengan baik. Faktor orang tua dan anak sama-sama menyumbang peran untuk keberhasilan hubungan mereka di antaranya usia orang tua, pendidikan orang tua, kondisi ekonomi orang tua, emosional orang tua, usia anak, kemampuan anak, dan situasi anak (Cahyati \& Kusumah, 2020: 154).

Cahyati \& Kusumah (2020: 156) dalam penelitiannya kemudian menyimpulkan bahwa di satu sisi hubungan orang tua dan anak-anaknya yang berusia 5-8 tahun menjadi semakin erat sejak belajar dari rumah di era Covid-19. Mengerjakan tugas sekolah bersama-sama antara orang tua dan anak membuat kegiatan belajar menjadi lebih efektif. Di sisi lain, selalu ada ketidaksepahaman di antara mereka terhadap suatu hal. Ketidaksepahaman itu menghasilkan kontradiksi. Hal ini yang disebut dengan dialektika relasional orang tua dan anak. Antara orang tua dan anak bisa terdapat perbedaan pendapat, perbedaan keinginan, perbedaan kemauan, atau perbedaan harapan. 
Penelitian terhadap hubungan orang tua dan anak dalam proses belajar di rumah di era Covid19 menjadi penting dilakukan untuk melihat lebih detil bagaimana dialektika relasional yang terjadi di antara mereka. Keluarga-keluarga yang tinggal di Kampung Tengah Kramat Jati Jakarta Timur menjadi objek penelitian ini. Mereka adalah dari keluarga dengan ekonomi kecil yang terdiri dari ayah yang sehari-hari harus terus bekerja untuk istri dan anak-anaknya. Terlebih di era Covid-19, ayah menjadi sangat sibuk mencari nafkah demi menekan kesulitan ekonomi akibat dampak pandemi dan PSBB di DKI Jakarta. Kesibukan ayah di luar rumah menjadi buruh, atau pedagang kecil, atau petugas keamanan membuatnya tidak bisa ikut mengawasi anak-anak di rumah. Sedangkan Ibu yang berada di rumah untuk mengurus rumah dan anak-anaknya yang masih bersekolah. Latar belakang pendidikan yang tidak tinggi, atau keahlian yang tidak cukup, atau pengalaman kerja yang tidak dipunyai, membuat ibu hanya berada di rumah sepanjang hari.

Dengan latar belakang tersebut, ibu dari keluarga di Kampung Tengah Kramat Jati Jakarta Timur menjadi sosok orang tua yang paling aktif mendampingi anak-anaknya di rumah termasuk pada masa belajar dari rumah di era Covid-19. Masa belajar dari rumah menuntut ibu memiliki kecakapan untuk mengajari, memberikan pemahaman, dan membimbing anakanaknya. Kurangnya kecakapan ibu dapat memicu debat-debat sepanjang komunikasinya bersama anak sebab anak menaruh harapan yang tinggi kepada ibunya agar dapat membantunya dalam menyelesaikan tugas-tugas sekolah. Sebaliknya, anak-anak yang tidak tertib pada saat belajar dapat memicu munculnya gejolak emosional karena ibu memiliki keinginan agar anak-anaknya bisa mengikuti pelajaran yang dilaksanakan dengan mode daring di rumah dengan baik.

Berdasarkan pemaparan di atas, masalah yang dapat dirumuskan yaitu "bagaimana dialektika relasional yang terjadi antara orang tua dan anak dari keluarga di Kampung Tengah Kramat Jati Jakarta Timur dalam proses belajar di era covid-19?"

Tujuan dari penelitian ini adalah untuk menganalisis dialektika relasional yang terjadi antara orang tua dan anak dari keluarga di Kampung Tengah Kramat Jati Jakarta Timur dalam proses belajar di era covid-19.

\section{KAJIAN TEORITIK}

\section{Dialektika Relasional}

Baxter dan Montgomery dalam Griffin (2012: 154) mengklaim bahwa kehidupan sosial itu begitu dinamis di mana tidak dapat dihindari akan selalu ada kontradiksi. Kontradiksi yang dimaksud terjadi pada hubungan dekat antarmanusia termasuk keluarga. Dalam hubungannya, selalu ada asumsi yang dibangun yang memunculkan argumen-argumen. West dan Turner dalam Putri \& Boer (2019: 72) menyebutkan empat asumsi dialektika dalam hubungan yakni sebagai berikut.

a. Hubungan tidak luput dari kontradiksi dari para pemeran hubungan itu.

b. Hubungan bersifat fluktuatif karena adanya kontradiksi dari para pemeran hubungan itu.

c. Hubungan selalu berubah karena kedekatan yang terjalin memengaruhi para pemeran dalam hubungan itu untuk mengungkapkan perasaannya.

d. Hubungan memerlukan komunikasi untuk mengelola kontradiksi yang terjadi.

Dialektika dalam hubungan terbangun karena adanya praktik dialogis dari para pemeran hubungan. Bakhtin dalam Nashrulloh (2019: 254) menyebutkan bahwa ada dua sisi pembentuk hubungan dialogis yaitu diri sendiri (self) dan diri orang lain (other). Self dan other adalah bagian-bagian yang tidak dapat dipisahkan. Self memerlukan other untuk memberikan 
penilaian sepenuhnya kepada self, demikian sebaliknya other terhadap self. Prinsipnya tidak ada satu individu yang bisa menilai dirinya sendiri kecuali dengan bantuan individu lain. Self dan other bersinergi untuk berkontribusi menciptakan kesadaran. Kontribusi dari mereka masing-masing menimbulkan sikap saling menanggapi keberadaan lawan-lawannya dalam hubungan itu.

Praktik dialogis yang tidak dapat dirawat dengan baik akan memicu munculnya konflik. Galvin dan Broomel dalam Wardyaningrum (2013: 52) menyebutkan bahwa ada dua jenis konflik dalam lingkungan keluarga yaitu pertama, konflik pada isu-isu utama yang berkaiatan dengan status di dalam keluarga dan kedua, konflik bukan pada isu-isu utama yang berkaitan dengan rutinitas keluarga sehari-hari.

\section{Hubungan Keluarga}

Keluarga adalah kumpulan individu yang terdiri dari ayah dan ibu yang kemudian disebut dengan orang tua, dan anak (Willis dalam Rohmatulloh, Istiyanto, \& Bestari, 2020: 100). Hubungan keluarga adalah hubungan sehari-hari yang paling dekat di mana di dalam hubungan tersebut orang tua dan anak menjalin komunikasi melalui tatap muka dalam bentuk verbal maupun nonverbal (Wahyuti \& Syarief, 2016: 144). Menurut Wiryanto dalam Hidayati (2020: 2) komunikasi tatap muka disebut pula dengan komunikasi interpersonal. Lebih lanjut Agus M. Hardjana dalam Hidayati (2020: 2) menyebutkan bahwa komunikasi interpersonal bercirikan adanya perilaku yang spontan, proses pengembangan, umpan balik, aturan-aturan yang ditetapkan, kegiatan timbal balik, dan dorongan untuk saling mengubah di antara dua individu.

Kesuksesan dalam menjalin komunikasi keluarga tersebut di atas didasari oleh peran masingmasing individu yang ada di dalam keluarga. Menurut Wood dalam Rohmatulloh dkk. (2020: 101) peran yang dimaksud adalah sebagai berikut.

a. Setiap individu di dalam keluarga memiliki tanggung jawab untuk menciptakan keseimbangan peran mereka.

b. Setiap individu peka terhadap kondisi keluarga sehingga mereka dapat menetapkan pilihan yang tepat pada setiap situasi.

c. Setiap individu saling menghargai dan memperhatikan agar terbangun rasa saling menyayangi.

d. Setiap individu mempertimbangkan perasaan yang lainnya agar mereka tidak terganggu.

Dalam hubungan keluarga, orang tua dan anak memiliki posisinya masing-masing. Pertama, orang tua merupakan bagian terdepan dalam struktur keluarga dalam penciptaan hubungan antarindividu melalui interaksi (Ruli, 2020: 144). Thibaut dan Kelley dalam Yunistiati, Djalali, \& Farid (2014: 73) menyatakan bahwa interaksi adalah kegiatan saling memengaruhi dalam proses komunikasi dua orang atau lebih. Interaksi tersebut membagun pengetahuan, pengalaman, dan perilaku. Kedua, anak-anak pada dasarnya membutuhkan asuhan dan pendidikan dari orang tua.

Selain untuk berinteraksi, hubungan orang tua dan anak dalam keluarga menjadi wadah pendidikan. Orang tua adalah tenaga pendidik di dalam hubungan mereka (Trisnawati dan Sugito, 2020: 823). Dalam mendidik anak, tentu ada materi yang disampaikan oleh orang tua 
kepada anak-anaknya. Materi tersebut mengandung nilai-nilai positif untuk dapat diserap dengan baik oleh anak-anaknya. Jailani (2014: 248) menyebutkan bahwa nilai pendidikan orang tua kepada anak tersebut dibangun dari pengamalan kebaikan-kebaikan, proses berbagi pengalaman-pengalaman, dan perwujudan kepribadian.

Orang tua dan anak menjadi semakin dekat dengan interaksi dan pendidikan tersebut. Dengan tinggal pada satu atap, keseharian mereka adalah berkomunikasi dalam banyak hal. Meskipun sehari-hari mereka yang senantiasa bersama-sama, setiap dari mereka adalah individu yang memiliki cara berpikir yang tidak sama. Fitzpatrick dan rekannya dalam Morissan (2013: 289) menyebutkan bahwa cara berpikir anggota keluarga disebut dengan skema hubungan yang di dalamnya terdiri atas pengetahuan mengenai diri sendiri, diri orang lain, dan hubungan yang sudah dikenal. Skema keluarga membentuk tipe-tipe keluarga yang berbeda yakni sebagai berikut.

a. Tipe Konsensual; di mana keluarga sangat sering melakukan percakapan dan memiliki kepatuhan yang tinggi. Kepatuhan tersebut menempatkan orang tua sebagai pihak yang membuat keputusan. Keluarga tipe ini adalah keluarga yang terbuka untuk saling mendengarkan satu sama lain.

b. Tipe Pluralistis; di mana keluarga sangat sering melalukan percakapan namun memiliki kepatuhan yang rendah. Setiap orang dalam keluarga akan membuat keputusannya masing-masing. Karena itu orang tua tidak merasa perlu mengontrol anak-anaknya. Pendapat yang terbaik adalah dasar pengambilan keputusan di antara mereka.

c. Tipe Protektif; di mana keluarga yang jarang melakukan percakapan namun memiliki kepatuhan yang tinggi. Orang tua dalam tipe keluarga ini merasa tidak memiliki alasan penting untuk berbicara dan mengungkapkan alasan mereka dalam memutuskan sesuatu.

d. Tipe Laissez-Faire; di mana keluarga jarang melakukan percakapan dan juga memiliki kepatuhan yang rendah. Setiap orang dalam tipe keluarga ini merasa tidak peduli dengan apa yang dikerjakan oleh yang lainnya dan apalagi membahasnya bersama-sama.

\section{METODOLOGI}

Penelitian ini menggunakan metode kualitatif. Cresswell (2016: 4) menjelaskan bahwa penelitian kualitatif adalah untuk mengeksplorasi dan memahami makna yang didapat dari sejumlah individu atau kelompok yang berasal dari masalah sosial. Dengan pendekatan fenomenologi, penelitian ini mengeksplorasi pengalaman ibu selaku orang tua dari keluargakeluarga yang tinggal di Kampung Tengah Kramat Jati Jakarta Timur selama kegiatan belajar dari rumah di era Covid-19 bersama anak-anaknya. Informan dalam penelitian ini ditentukan dengan teknik purposeful sampling dengan jenis criterion sampling sehingga mendapatkan informan sesuai kriteria yang ditetapkan. Kriterianya adalah ibu-ibu yang berperan sebagai ibu rumah tangga yang kesehariannya mengurus keluarga, memiliki suami yang sibuk bekerja di luar rumah, dan memiliki anak yang masih bersekolah pada tingkat Sekolah Dasar di kelas 2-3. Pengumpulan data dilakukan dengan wawancara mendalam kepada para informan dan observasi tidak tersrtuktur pada kondisi lapangan. Data yang terkumpul dianalis dengan pendekatan interpretative approach agar menghasilkan tulisan yang deskriptif. 
Aktivitas belajar dari rumah tidak hanya melibatkan anak-anak yang sedang bersekolah saja. Orang tua mereka masing-masing berperan dalam mendukung proses belajar yang baik selama di rumah. Orang tua mendampingi anak-anaknya yang melangsungkan kegiatan belajar dengan mode daring di samping mereka harus melakukan aktivitas lain. Tidak kedua orang tua dari keluarga di Kampung Tengah Kramat Jati Jakarta Timur yang memiliki kesediaan untuk bersama-sama mendampingi anaknya belajar. Ayah sibuk bekerja di luar rumah untuk mecari nafkah. Oleh karena itu, Ibu mengambil peran untuk berada di samping anaknya selama belajar daring di era Covid-19.

Ibu memiliki aktivitas yang cukup padat di rumah. Ibu bekerja mengurus keperluan rumah. Ibu juga mengurus keperluan anak-anaknya yang lain. Di saat ibu disibukkan dengan banyak urusan sedangkan ia tetap harus mengawal anaknya yang sedang belajar dari rumah, di saat tersebut muncul dialektika antara ibu dan anak.

\section{Dialektika saat Proses Belajar dari Rumah}

Dialog antara orang tua dan anak dari keluarga di Kampung Tengah Kramat Jati Jakarta Timur dimulai pada saat pagi hari di saat semua aktivitas di dalam rumah baru dimulai. Ibu mengurus segala keperluan rumah seperti menyiapkan sarapan pagi, membangunkan anak-anak, dan menyiapkan keperluan sekolah anak-anak. Jumlah urusan mereka yang tidak sama antara Ibu dan anak memicu komunikasi yang mengandung kontradiksi.

1. Pemindahan proses belajar dari sekolah ke rumah menambah deret panjang urusan ibu selama di rumah karena ibu harus turut mendampingi anak-anaknya juga saat belajar di rumah di era Covid-19. Meski guru dari sekolah tetap melaksanakan fungsinya dalam memberikan pemahaman kepada anak terkait suatu materi, namun ibu mengambil peran yang lebih banyak selama proses belajar berlangsung seperti mempersiapkan media untuk belajar daring serta ikut memeriksa tugas-tugas sekolah anak. Kondisi ini menyebabkan komunikasi ibu dan anak kerap diwarnai percekcokan. Mama Wilda yang suaminya bekerja sebagai pedagang kecil harus mengurusi anak-anaknya sendiri di rumah. Sembari mengurus tiga orang anak yang lain, ada kesulitan dalam membimbing satu anaknya yang duduk di bangku kelas $2 \mathrm{SD}$. Anak yang masih bersekolah dasar belum memiliki tanggung jawab untuk dirinya sendiri sehingga segala bentuk keperluannya masih harus dibantu oleh ibunya. Dalam dialog di antara ibu dan anak terdapat dialektika. Dialektika terjadi karena ketidaksamaan tanggung jawab.

2. Ibu selaku orang tua memiliki ekspektasi terhadap anak-anaknya untuk menjadi lebih baik dari dirinya. Hal ini dilatarbelakangi karena ibu yang sudah tidak lagi duduk di bangku sekolah tidak memiliki pemahaman yang cukup dengan materi pelajaran sekolah anaknya. Terlebih lagi kurikulum yang diajarkan dari masa ibu yang dulu pernah bersekolah dibandingkan dengan anaknya yang bersekolah pada saat ini sudah jauh berbeda. Pada saat belajar dari rumah, anak-anak cenderung memilih ibunya sebagai tempat yang dapat ditanyai bila mereka tidak memahami suatu materi. Mama Amel yang suaminya bekerja sebagai pedagang kecil harus mengurus dua orang anaknya sendiri di rumah. Ia mengaku kebingungan saat ditanyai anaknya yang duduk di kelas 2 SD terkait materi pelajaran di sekolah. Ketidakmampuan ibu dalam menjawab pertanyaan anak memunculkan debat-debat saat berkomunikasi dengan anaknya. Dialektika terjadi karena ketidaksamaan ekspektasi. 
3. Proses belajar dari rumah di era Covid-19 mendekatkan ibu dan anak. Komunikasi mereka terbangun karena pembahasan materi-materi pelajaran. Ibu dengan pemahamannya yang terbatas berupaya membantu anaknya menyelesaikan tugas-tugas yang diberikan dari sekolah. Anak dengan pemahaman yang masih minim berupaya menelaah maksud dan pengertian dari ibunya. Mama Shireen yang suaminya bekerja sebagai petugas keamanan dengan jadwal shifting harus mengurusi sendiri empat orang anaknya di rumah yang kesemuanya masih bersekolah. Ia mengungkapkan bahwa antara ia dan anaknya yang bersekolah di kelas 3 SD sering berdebat terhadap suatu tema yang berkaitan dengan soal-soal tugas sekolah. Ibu memiliki persepsi dari pemahamannya. Anak pun memiliki persepsi dari pemahamannya. Kasus ini menunjukkan bahwa pemahaman dari persepsi ibu dan anak sama-sama tidak diserap dengan mudah oleh satu sama lain sehingga memicu perbedaan pendapat. Dialektika terjadi karena ketidaksamaan persepsi.

Ketidaksamaan tanggung jawab, ekspektasi, dan persepsi yang terjadi antara ibu dan anak dari keluarga di Kampung Tengah Kramat Jati Jakarta Timur mendorong keduabelah pihak melakukan tindak lanjut atas dialektika yang terjadi. Komunikasi dua arah dilakukan untuk mencapai kesepakatan dalam hubungan ibu dan anak. Kesepatakan tersebut untuk memahami peran masing-masing pihak di masa mendatang, menyelesaikan masalah, menilai satu sama lain, dan mencegah konflik. Baik Mama Wilda, Mama Amel, dan Mama Shireen memilih berdialog dengan anaknya masing-masing untuk mengomunikasikan konsep diri mereka. Seperti yang diungkapkan oleh Bakhtin dalam Nashrulloh (2019: 254), dialog dimaknai sebagai pemahaman bahwa setiap komunikasi melibatkan ragam karakter individu yang perlu dipersatukan dengan penilaian-penilaian.

\section{Dialektika sebagai Realitas Hubungan}

Dialektika yang terjadi antara ibu dan anak dari keluarga di Kampung Tengah Kramat Jati Jakarta Timur di saat belajar daring pada era Covid-19 melahirkan temuan-temuan hasil konstruksi komunikasi antara keduanya. Temuan-temuan tersebut adalah bentuk realitas dalam hubungan.

1. Banyaknya keperluan yang mesti diurus oleh ibu di rumah ditambah keharusan untuk mendampingi anak belajar daring pada era Covid-19 membuat mereka lelah dan mudah emosional. Proses belajar bersama anak yang tidak mudah menjadi peluang bagi ibu untuk meluapkan emosinya. Mama Wilda, Mama Amel, dan Mama Shireen kerap marah pada anaknya masing-masing yang bersekolah di Sekolah Dasar saat menemukan mereka tidak tertib selama proses belajar. Kontradiksi hubungan terjadi antara orang tua yang melibatkan emosinya dengan anak yang tidak melibatkan emosinya.

2. Pada masa belajar dari rumah di era Covid-19, kebiasaan anak berubah dari berangkat ke sekolah di pagi hari menjadi bangun pagi dengan perasaan santai. Mama Wilda mendapati anaknya yang bersekolah di kelas 2 SD sulit bangun pagi setelah program belajar di rumah berlangsung. Rumah adalah selayaknya tempat bermain bagi anak. Sehingga keharusan belajar dari rumah disikapi anak sebagai sesuatu yang tidak serius. Kontradiksi hubungan terjadi antara orang tua yang mengutamakan ketertiban dengan anak yang tidak peduli dengan ketertiban.

3. Pendampingan yang dilakukan oleh ibu pada masa belajar dari rumah di era Covid-19 disertai dengan pemenuhan pemahaman anak terhadap materi pelajaran sekolah yang disampaikan langsung oleh ibu. Dalam proses belajar, ibu berperan selayaknya guru 
untuk memeriksa pengerjaan tugas-tugas anak dari sekolah. Mama Wilda mengakui pendampingan yang dilakukan menjadikan anaknya yang bersekolah di kelas 2 SD bersikap manja. Kehadiran ibu di sisi anak saat anak menghadapi suatu persoalan memicu ketergantungan bagi anak. Ketergantungan tersebut ditunjukkan dengan sikap manja anak kepada ibu. Kontradiksi hubungan terjadi antara orang tua yang mengajarkan kemadirian dengan anak yang bersikap manja.

Bentuk-bentuk realitas kontradiksi tersebut berlangsung selama proses belajar. Tidak terdapat konflik berkelanjutan akibat dialektika antara ibu dan anak. Kedua pihak melanjutkan komunikasinya untuk tetap saling dekat dan saling memahami. Pada akhirnya dialektika menjadi perekat hubungan ibu dan anak. Seperti yang diungkapkan West dan Turner dalam Putri \& Boer (2019: 72) bahwa komunikasi adalah cara terbaik untuk menghindari konflik.

Komunikasi ibu dan anak menghantarkan mereka untuk berpikir terkait satu sama lain. Morissan (2013: 289) menyampaikan bahwa keluarga yang sangat sering melakukan percakapan akan menciptakan suasana keluarga yang terbuka dan mau mendengarkan satu sama lain. Selain itu komunikasi yang baik akan menempatkan orang tua sebagai pihak yang harus dipatuhi oleh anak karena orang tua berperan untuk membuat keputusan-keputusan bagi mereka. Keluarga dengan tipe konsensual ini terbentuk pada keluarga Mama Wilda, Mama Amel, dan Mama Shireen. Meski ada dialektika dalam hubungan ibu dan anak selama belajar dari rumah di era Covid-19, keharmonisan mereka tetap terjaga karena komunikasi yang baik.

\section{KESIMPULAN}

Dari pemaparan mengenai Dialektika Relasional Orang Tua dan Anak dalam Proses Belajar di Era Covid-19 tersebut di atas maka dapat disimpulkan bahwa hubungan orang tua dan anak dari keluarga di Kampung Tengah Kramat Jati Jakarta Timur merupakan bentuk hubungan yang dinamis namun erat. Orang tua dan anak memiliki fungsinya masing-masing. Dalam konteks keluarga, orang tua yang merupakan struktur terdepan di dalam keluarga berlaku sebagai pihak yang mengambil keputusan dan anak berlaku sebagai pihak yang mematuhi keputusan tersebut. Dalam konteks belajar, orang tua berlaku sebagai tenaga pendidik karena didasari pada kodrat mereka untuk mendidik segala sesuatu di dalam keluarga dan anak berlaku sebagai pihak yang harus menyerap pendidikan tersebut. Fungsi-fungsi orang tua dan anak tersebut dipersatukan melalui proses komunikasi. Dialog dalam komunikasi membangun dialektika dan melalui dialog pula konflik dapat dihindari.

Proses belajar di rumah pada era Covid-19 menjadi wadah bagi orang tua dan anak agar mereka kian dekat. Selama proses belajar berlangsung ditemukan ketidaksamaan di antara mereka dalam berbagai hal. Ketidaksamaan tersebut memicu kontradiksi dalam hubungan berkomunikasi. Dalam kasus-kasus hubungan ibu dan anak dari keluarga di Kampung Tengah Kramat Jati Jakarta Timur menunjukkan bahwa kontradiksi dalam proses belajar merupakan bagian hubungan yang fluktuatif. Hubungan diwarnai ketegangan di saat belajar dan menjadi harmonis usai belajar.

Peneliti merekomendasikan agar para orang tua tidak melibatkan dorongan emosional karena kontradiksi yang terjadi dalam hubungannya dengan anak terutama pada proses belajar. Kegiatan belajar adalah kegiatan untuk mendalami ilmu pengetahuan. Orang tua berperan untuk membantu anak dalam memahami pengetahuan tersebut. Jika proses belajar dicampuri dengan emosional, tidak hanya target pemahaman anak yang tidak dapat terpenuhi karena 
anak menjadi cenderung takut atau kesal atau manja, melainkan juga komunikasi orang tua dan anak menjadi buruk.

Dalam hal akademis, peneliti mendorong agar penelitian selanjutnya dapat menganalisis dengan lebih mendalam bagaimana dialektika relasional yang terjadi pada hubungan orang tua dan anak.

\section{DAFTAR PUSTAKA}

. (2020). Kemendikbud Terbitkan Pedoman Penyelenggaraan Belajar dari Rumah. https://www.kemdikbud.go.id/main/blog/2020/05/kemendikbud-terbitkanpedoman-penyelenggaraan-belajar-dari-rumah Diakses pada 17 November 2020

(2020). Perjalanan PSBB Jakarta Hingga Kembali ke Titik Nol. https://www.cnnindonesia.com/nasional/20200911061829-20-

545178/perjalanan-psbb-jakarta-hingga-kembali-ke-titik-nol Diakses pada 18 Oktober 2020

Baskara, B. (2020). Rangkaian Peristiwa Pertama Covid-19. https://bebas.kompas.id/baca/riset/2020/04/18/rangkaian-peristiwa-pertamacovid-19/ Diakses pada 18 Oktober 2020

Cahyati, N., \& Kusumah, R. (2020). Peran Orang Tua dalam Menerapkan Pembelajaran di Rumah Saat Pandemi Covid 19. Jurnal Golden Age, 4(01), 152-159. https://doi.org/10.29408/iga.v4i01.2203

Creswell, J. W. (2016). Research Design: Pendekatan Metode Kualitatif, Kuantitatif, dan Campuran (4th Ed.). Yogyakarta: Pustaka Pelajar.

Griffin, Em. (2012). A First Look at Communication Theory (Eight Edit). New York: McgrawHill.

Harmaini. (2013). Keberadaan Orang Tua Bersama Anak. Jurnal Psikologi UIN Sultan Syarif Kasim Riau (Vol. 9, Issue 2, pp. 80-93).

Hidayati, R. (2020). Peran Orang Tua: Komunikasi Tatap Muka dalam Mengawal Dampak Gadget pada Masa Golden Age. SOURCE: Jurnal Ilmu Komunikasi, 5(2), 1-10. https://doi.org/10.35308/source.v5i2.1396

Ihsanuddin. (2020). Jokowi: Kerja dari Rumah, Belajar dari Rumah, Ibadah di Rumah Perlu Digencarkan. https://nasional.kompas.com/read/2020/03/16/15454571/jokowikerja-dari-rumah-belajar-dari-rumah-ibadah-di-rumah-perlu-digencarkan?page=all Diakses pada 18 Oktober 2020

Jailani, M. S. (2014). Teori Pendidikan Keluarga dan Tanggung Jawab Orang Tua dalam Pendidikan Anak Usia Dini. Nadwa, Jurnal Pendidikan Islam, 8(2), 245-260.

Morissan. (2013). Teori Komunikasi Individu Hingga Massa. Jakarta: Prenadamedia Group.

Nasrulloh, M. (2019). Pola Hubungan Relasional pada Pasangan Sejenis (Sebuah Penelitian Empiris dengan Perspektif Teori Dialektika Relasional). Jurnal Dakwah Tabligh, 20(2), 251-266. https://doi.org/10.24252/idt.v20i2.9446 
Prodjo, Wahyu Adityo Prodjo. (2020). Apa itu Belajar dari Rumah? Melihat Kembali Konsep Awal... $\quad$ https://edukasi.kompas.com/read/2020/04/14/163041771/apa-itubelajar-dari-rumah-melihat-kembali-konsep-awal?page=all Diakses pada 17 November 2020

Putri, M. S. N., \& Boer, R. F. (2019). Ekstensi Dinamika Dialektika Interpersonal pada Relasi Antara Department Media \& Public Relations Inasgoc dengan Media di 18th Asian Games Invitation Tournament. Mediakom: Jurnal Ilmu Komunikasi, 3(1), 67-83. https://doi.org/10.35760/mkm.2019.v3i1.1983

Rohmatulloh, A. M., Istiyanto, S. B., \& Bestari, D. (2020). YouTube sebagai Media Pengendalian Orang Tua Terhadap Anak (Studi Kasus Parental Mediation Orang Tua Terhadap Siswa SDIT Al-Marjan Bekasi). SOURCE: Jurnal Ilmu Komunikasi, 6(1), 100-107.

Ruli, E. (2020). Tugas dan Peran Orang Tua dalam Mendidk Anak. Jurnal Edukasi Nonformal, 143-146.

Trisnawati, W., \& Sugito. (2020). Pendidikan Anak dalam Keluarga Era Covid-19. Jurnal Obsesi: Jurnal Pendidikan Anak Usia Dini, 5(1), 823-831. https://doi.org/10.31004/obsesi.v5i1.710

Wahyuti, T., \& Syarief, L. K. (2016). Korelasi Antara Keakraban Anak dan Orang Tua dengan Hubungan Sosial Asosiatif Melalui Komunikasi Antarpribadi. Jurnal Visi Komunikasi, 15(01), 143-157.

Wardyaningrum, D. (2013). Komunikasi untuk Penyelesaian Konflik dalam Keluarga: Orientasi Percakapan dan Orientasi Kepatuhan. Jurnal Al-Azhar Indonesia Seri Pranata Sosial, 2(1), 47-58. eprints.uai.ac.id/12/1/110-506-1-SM.pdf\%0A\%0A

Yunistiati, F., Djalali, M. A., \& Farid, M. (2014). Keharmonisan Keluarga, Konsep Diri dan Interaksi Sosial Remaja. Persona: Jurnal Psikologi Indonesia, 3(01), 71-82. https://doi.org/10.30996/persona.v3i02.380 